\title{
Oxygen desaturation in healthy subjects undergoing the incremental shuttle walk test*
}

\author{
Dessaturação em indivíduos saudáveis submetidos ao incremental \\ shuttle walk test
}

\author{
Daniel Machado Seixas, Daniela Miti Tsukumo Seixas, Monica Corso Pereira, \\ Marcos Mello Moreira, llma Aparecida Paschoal
}

\begin{abstract}
Objective: To determine the probability of oxygen desaturation in healthy individuals undergoing the incremental shuttle walk test (ISWT). Methods: We enrolled 83 healthy subjects: 55 males (including 1 smoker) and 28 females. We determined pre-1SWT FEV $, \mathrm{FEV}_{6}, \mathrm{HR}$ and $\mathrm{SpO}_{2}$, as well as post-1SWT HR and $\mathrm{SpO}_{2}$. Results: Mean values overall were as follows: age, $35.05 \pm 12.53$ years; body mass index, $24.30 \pm 3.47 \mathrm{~kg} / \mathrm{m}^{2}$; resting $\mathrm{HR}$, $75.12 \pm 12.48 \mathrm{bpm}$; resting $\mathrm{SpO}_{2}, 97.96 \pm 1.02 \% ; \mathrm{FEV}_{1}, 3.75 \pm 0.81 \mathrm{~L} ; \mathrm{FEV}_{6}, 4.45 \pm 0.87 \mathrm{~L} ; \mathrm{FEV}_{1} / \mathrm{FEV}_{6}$ ratio, $0.83 \pm 0.08$ (no restriction or obstruction); incremental shuttle walk distance, $958.30 \pm 146.32 \mathrm{~m}$; post-1SWT $\mathrm{HR}, 162.41 \pm 18.24 \mathrm{bpm}$; and post-1SWT Sp0, $96.27 \pm 2.21 \%$. In 11 subjects, post-1SWT SpO ${ }_{2}$ was higher than was pre-1SWT $\mathrm{SpO}_{2}$. In 17 subjects, there was a 4\% decrease in $\mathrm{SpO}_{2}$ after the 1SWT. There were no statistically significant differences between the groups with and without post-1SWT oxygen desaturation in terms of age, gender, $\mathrm{FEV}_{1}, \mathrm{FEV}_{6}, \mathrm{FEV}_{1} / \mathrm{FEV}_{6}$, pre-1SWT $\mathrm{SpO}_{2}$, incremental shuttle walk distance, HR, or percentage of maximal HR. In the individuals with post-1SWT oxygen desaturation, the body mass index was higher $(p=0.01)$ and post-ISWT $\mathrm{SpO}_{2}$ was lower $(\mathrm{p}=0.0001)$. Conclusions: Healthy individuals can present oxygen desaturation after the ISWT. Using the 1SWT to predict subtle respiratory abnormalities can be misleading. In healthy subjects, oxygen desaturation is common after the ISWT, as it is during any intense physical activity.
\end{abstract}

Keywords: Heart function tests; Respiratory function tests; Body mass index; 0ximetry

\section{Resumo}

Objetivo: Determinar a probabilidade de dessaturação arterial em indivíduos saudáveis submetidos ao incremental shuttle walk test (1SWT). Métodos: Foram estudados 83 indivíduos saudáveis, dos quais 55 eram homens ( 1 deles fumante) e 28 eram mulheres. Foram determinados $\mathrm{VEF}_{1}$ e $\mathrm{VEF}_{6}$ antes da realização do ISWT, assim como FC e $\mathrm{SpO}_{2}$ antes e depois do 1SWT. Resultados: As médias gerais foram as seguintes: idade, 35,05 \pm 12,53 anos; índice de massa corporal, 24,30 \pm 3,47 kg/m²; FC em repouso, 75, $12 \pm 12,48 \mathrm{bpm}$; $\mathrm{SpO}_{2}$ em repouso, 97,96 \pm 1,02\%; $\mathrm{VEF}_{1}, 3,75 \pm 0,81 \mathrm{~L} ; \mathrm{VEF}_{6}, 4,45 \pm 0,87 \mathrm{~L}$; relação $\mathrm{VEF}_{1} / \mathrm{VEF}_{6}, 0,83 \pm 0,08$ (sem restrição ou obstrução); distância percorrida no 1SWT, 958,30 \pm 146,32 m; FC pós-1SWT, 162,41 \pm 18,24 bpm e Sp0 pós-1SWT, 96,27 \pm 2,21\% Em 11 indivíduos, houve um aumento da $\mathrm{SpO}_{2}$ após o 1SWT, ao passo que em 17 houve uma queda de 4\%. Não houve diferença estatística entre os grupos com e sem dessaturação após o 1SWT no tocante às variáveis idade, gênero, $\mathrm{VEF}_{1}, \mathrm{VEF}_{6}, \mathrm{VEF}_{1} / \mathrm{VEF}_{6}, \mathrm{SpO}_{2}$ basal, distância percorrida no $\mathrm{ISWT}$, FC e porcentagem da FC máxima. Nos indivíduos que apresentaram dessaturação, o índice de massa corporal foi maior $(p=0,01)$ e a $\mathrm{SpO}_{2}$ pós-1SWT foi menor ( $p$ = 0,0001). Conclusões: Indivíduos saudáveis podem apresentar dessaturação após o 1SWT. 0 uso do 1SWT para prever a presença de problemas respiratórios sutis pode ser enganador. Em indivíduos saudáveis, a dessaturação é um evento comum após o ISWT, assim como o é durante a atividade física intensa.

Descritores: Testes de função cardíaca; Testes de função respiratória; Índice de massa corporal; Oximetria.

*Study carried out at the State University at Campinas, Campinas, Brazil.

Correspondence to: 1lma Aparecida Paschoal. Cidade Universitária "Zeferino Vaz", Disciplina de Pneumologia, FCM-UNICAMP, Distrito de Barão Geraldo, CEP 13083-888 Campinas, SP, Brasil.

Tel. 5519 3521-7948. E-mail: ilma@fcm.unicamp.br

Financial support: None.

Submitted: 23 April 2013. Accepted, after review: 9 July 2013. 


\section{Introduction}

Although patients with interstitial pulmonary fibrosis or pulmonary arterial hypertension can have normal $\mathrm{SpO}_{2}$ at rest, some will show oxygen desaturation after submaximal exercise. $(1,2)$ End-exercise $\mathrm{PaO}_{2}$ decreases after maximal exercise, and submaximal steady-state exercise was found to be an important measure of disease severity in interstitial pulmonary fibrosis. ${ }^{(3,4)}$ Lama et al. demonstrated that patients with usual interstitial pneumonia who developed oxygen desaturation during and after a six-minute walk test (6MWT)-a $\geq 4 \%$ decrease in oxygen saturation from baseline ( $\Delta$ sat $\geq 4 \%$ ) -were more than four times more likely to die during follow-up. ${ }^{(5)}$ The abovementioned findings led us to hypothesize that a decrease in oxygen saturation during selfpaced walking (a submaximal exercise test) is a meaningful measure of disease status in patients with scleroderma. Our results showed that, in the multiple logistic regression analysis, the variable $\Delta$ sat $\geq 4 \%$ was significantly associated with age, dyspnea, and two other variables related to pulmonary involvement, i.e., FVC $<80 \%$ of the predicted value (as assessed by spirometry) and positivity for the Scl-70 antibody, which is a marker of pulmonary disease in scleroderma. However, the statistical model applied to the data did not indicate which of the dependent variables analyzed ( $\Delta$ sat $\geq 4 \%$ or the distance walked) was better at predicting pulmonary disease. Nevertheless, $\Delta$ sat $\geq 4 \%$ appeared to be able to provide more information on this issue than did the distance walked. ${ }^{(6)}$

Another study conducted by our research group and involving patients with systemic lupus erythematosus showed that those with post-6MWT $\Delta$ sat $\geq 4 \%$ (as assessed by pulse oximetry) showed a significant reduction in the six-minute walk distance (6MWD), which was $443 \mathrm{~m}$ in the group of patients who developed oxygen desaturation and $497 \mathrm{~m}$ in that of those who did not ( $\mathrm{p}=$ 0.0291). However, both 6MWDs were well above the lower limit of the normal range. In addition, when compared with the patients who did not develop oxygen desaturation, those who did had a higher post-6MWT HR ( $p=0.0170)$, a lower $\operatorname{MEP}(p=0.0282)$, a lower MIP $(p=0.0504)$, and a restrictive pattern of lung disease (as determined by spirometry). These findings suggest that oxygen desaturation is more sensitive in detecting the presence of respiratory abnormalities in patients with systemic lupus erythematosus than is the 6MWD (unpublished data). Therefore, oxygen desaturation during submaximal exercise seems to be a more sensitive endpoint to detect subtle respiratory abnormalities in pulmonary diseases and in systemic diseases that affect respiration.

Maximal exercise tests, such as cardiopulmonary exercise tests, can provide important information on the integration between the cardiovascular and respiratory systems during exercise. Although cardiopulmonary exercise tests have been extensively used in order to investigate various lung diseases, they are complex tests that require expensive equipment.

The incremental shuttle walk test (ISWT) is a maximal exercise test that provides data that correlate well with measurements made during incremental cardiopulmonary exercise testing, being simpler and less expensive than the latter. The fact that even patients with few symptoms and mild pulmonary involvement can present with a decrease in oxygen saturation in a submaximal test led to us inquire how oxygen saturation would behave during a maximal walk test, such as the 1SWT. Could it improve the sensitivity of the 6MWT in detecting respiratory impairment? With the objective of exploring this hypothesis, we decided to perform the ISWT in healthy individuals in order to determine the probability of oxygen desaturation at the end of the test.

\section{Methods}

This was a cross-sectional study involving healthy subjects who attended a private fitness center in the city of Campinas, Brazil. All of the enrolled subjects attended the fitness center in order to keep physically active and in good health, and none were professional athletes. They were invited to participate in the study and agreed to perform the tests included in the protocol.

The study was approved by the Research Ethics Committee of the Universidade Estadual de Campinas (Unicamp, State University at Campinas) Hospital de Clínicas, located in the city of Campinas, Brazil, and all participants gave written informed consent.

Subjects were considered ineligible for the ISWT if they had a history of lung or heart disease or any other health condition that might preclude the performance of the ISWT. A standard questionnaire was applied to all participants to ensure that they did not meet any of the exclusion criteria. 
A digital peak flow meter (Koko Peak Pro 6; Ferraris Cardiorespiratory PDS Healthcare Products Inc., Louisville, CO, USA) was used in order to determine pre-1SWT FEV ${ }_{1}$ and FEV $_{6}$. The FEV ${ }_{1} I$ FEV $_{6}$ ratio was calculated by the device and was displayed on the screen. Each subject performed at least three forced expiratory maneuvers after maximal inspiratory maneuvers, the best maneuver being automatically chosen by the peak flow meter.

Pre-ISWT HR and oxygen saturation were determined with a pulse oximeter equipped with a finger probe (Nonin Medical, Inc., Plymouth, MN, USA). Fingernail polish, if worn by the subject, was removed before testing. In order to guarantee an accurate assessment of oxygen saturation, the principal investigator checked that the pulse oximeter showed an acceptable pulse signal and that the oximeter light was green and pulsing in synchrony with the HR before the beginning of the tests.

The protocol used for the ISWT was the 12-level version proposed by Singh et al..$^{(7)}$ for functional capacity evaluation in patients with COPD. All participants were tested under standardized conditions by the same investigator. The walking course was level, being $10 \mathrm{~m}$ in length. It was delimited by two cones inset $0.5 \mathrm{~m}$ from either end to avoid the need for abrupt changes in direction. The speed at which subjects walked was dictated by an audio signal played on a portable microcomputer. Each participant received a standardized explanation ("you should walk at a steady pace, aiming to turn around whenever you hear the signal; you should continue to walk until you feel that you are unable to maintain the required speed"). At the first level of the test, the calculated walking speed was $0.5 \mathrm{~m} / \mathrm{s}$ and the number of expected shuttles was 3 ; at the twelfth level, walking speed was $2.37 \mathrm{~m} / \mathrm{s}$ and 14 shuttles were expected. All subjects were carefully observed during the test so that they would not exceed their exercise limit.

Oxygen saturation was also measured immediately after the end of the 1SWT. For the purpose of data analysis, oxygen desaturation was defined as a $\geq 4 \%$ decrease in oxygen saturation $\left(\mathrm{SpO}_{2}\right)$ from baseline $(\Delta \mathrm{sat}=$ oxygen saturation at rest - oxygen saturation immediately after the 1SWT). This 4\% decrease in oxygen saturation was validated in studies of exercise-induced hypoxemia during maximal exercise tests in athletes. (8) Maximum incremental shuttle walk distance (ISWD) was defined as the maximum distance that the subjects were able to walk during the ISWT.

Table 1 - Comparison between the two groups (with and without oxygen desaturation).

\begin{tabular}{|c|c|c|c|}
\hline \multirow[t]{2}{*}{ Variable } & OD & No OD & \multirow[t]{2}{*}{$p$} \\
\hline & $(n=17)$ & $(n=66)$ & \\
\hline Age & $38.65 \pm 13.77$ & $34.12 \pm 12.13$ & NS \\
\hline BMl & $26.59 \pm 3.85$ & $23.71 \pm 3.14$ & 0.01 \\
\hline $\mathrm{FEV}_{1}$ & $3.53 \pm 0.67$ & $3.80 \pm 0.84$ & NS \\
\hline $\mathrm{FEV}_{6}$ & $4.34 \pm 0.56$ & $4.48 \pm 0.93$ & NS \\
\hline $\mathrm{FEV}_{1} / \mathrm{FEV}_{6}$ & $0.83 \pm 0.11$ & $0.84 \pm 0.08$ & NS \\
\hline LLN & $3.95 \pm 0.68$ & $3.82 \pm 0.78$ & NS \\
\hline Initial HR, bpm & $73.76 \pm 10.16$ & $75.47 \pm 13.06$ & NS \\
\hline Final HR, bpm & $160.47 \pm 20.59$ & $162.91 \pm 17.72$ & NS \\
\hline Initial $\mathrm{SpO}_{2}, \%$ & $97.88 \pm 0.99$ & $97.99 \pm 1.03$ & NS \\
\hline Final $\mathrm{SpO}_{2}, \%$ & $93.12 \pm 1.76$ & $97.08 \pm 1.46$ & 0.0001 \\
\hline$\Delta \mathrm{SpO}_{2}$ & $4.77 \pm 1.15$ & $0.91 \pm 1.27$ & 0.0001 \\
\hline ISWD & $956.50 \pm 127.10$ & $958.80 \pm 151.80$ & NS \\
\hline Maximal HR, bpm & $181.53 \pm 13.96$ & $185.88 \pm 12.13$ & NS \\
\hline Maximal HR, \% & $88.29 \pm 9.34$ & $87.64 \pm 9.62$ & NS \\
\hline Recovery HR, \% & $91.24 \pm 15.16$ & $92.24 \pm 17.93$ & NS \\
\hline Recovery $\mathrm{SpO}_{2}, \%$ & $97.29 \pm 0.99$ & $97.70 \pm 1.07$ & NS \\
\hline
\end{tabular}

OD: oxygen desaturation; BMI: body mass index; ISWD: incremental shuttle walk distance; LLN: lower limit of normality; and NS: not significant. ${ }^{a}$ Values expressed as mean \pm SD. 
Table 2 - Proportions of individuals who reached more than $85 \%$ or $85 \%$ or less of the predicted maximal HR in the two groups. ${ }^{a}$

\begin{tabular}{ccc}
\hline Maximal HR & OD & No OD \\
\hline$>85 \%$ & $12(71)$ & $47(71)$ \\
$\leq 85 \%$ & $5(29)$ & $19(29)$ \\
Total & $17(100)$ & $66(100)$ \\
\hline
\end{tabular}

OD: oxygen desaturation. ${ }^{a}$ Values expressed as $\mathrm{n}(\%)$.

$A \geq 4 \%$ decrease in oxygen saturation was used in order to divide the study population into two groups. The Anderson-Darling test was applied to the measured variables and the demographic characteristics of the two groups to determine their distribution. Variables with normal distribution were analyzed with the Student's t-test. Variables with non-normal distribution were analyzed with the Wilcoxon test. Categorical data were compared by the chi-square test or Fisher's exact test. The statistical analysis was performed with the SAS software, version 8 (SAS Institute, Inc., Cary, NC, USA). Differences were considered significant at $p<0.05$.

\section{Results}

Eighty-three individuals who attended a fitness center in the city of Campinas, Brazil, were invited and agreed to participate in the study. Of those, 55 were male and 28 were female. Only 1 was a smoker. The mean age was $35.05 \pm 12.53$ years, the median being 32 years. The mean body mass index (BMI) was $24.30 \pm 3.47 \mathrm{~kg} / \mathrm{m}^{2}$, the median being $24.5 \mathrm{~kg} / \mathrm{m}^{2}$. The mean resting HR was 75.12 $\pm 12.48 \mathrm{bpm}$, the median being $73 \mathrm{bpm}$. The mean pre-1SWT $\mathrm{SpO}_{2}$ was $97.96 \pm 1.02 \%$, the median being $98 \%$. The mean $\mathrm{FEV}_{1}$ was $3.75 \pm$ $0.81 \mathrm{~L}$, the median being $3.65 \mathrm{~L}$. The mean $\mathrm{FEV}_{6}$ was $4.45 \pm 0.87 \mathrm{~L}$, the median being $4.38 \mathrm{~L}$. The mean $\mathrm{FEV}_{1} / \mathrm{FEV}_{6}$ ratio was $0.83 \pm 0.08$, the median being 0.82 . In all enrolled subjects, measured FEV $_{6}$ was above the lower limit of the predicted FVC (as determined by the equations devised for the Brazilian population), and all subjects had a $\mathrm{FEV}_{1} / \mathrm{FEV}_{6}$ ratio $\geq 0.8$. These findings allow the assumption that none of the participants had restrictive or obstructive lung disease (Table 1).

The mean ISWD was $958.30 \pm 146.32 \mathrm{~m}$, the median being $1,020 \mathrm{~m}$. The mean postISWT HR was $162.41 \pm 18.24 \mathrm{bpm}$, the median being $166 \mathrm{bpm}$. The mean post-1SWT SpO was $96.27 \pm 2.21 \%$. In 11 subjects, post-1SWT oxygen saturation values were higher than pre-ISWT oxygen saturation values. In 17 subjects, oxygen saturation had decreased by $\geq 4 \%$ by the end of the test. $\ln 2$ subjects, $\mathrm{SpO}_{2}$ was $<92 \%$ (Table 2).

The study population was divided into two groups on the basis of the presence of a post1SWT oxygen desaturation $\geq 4 \%$. No differences were found between the two groups regarding age, gender, $\mathrm{FEV}_{1}, \mathrm{FEV}_{6}, \mathrm{FEV}_{1} / \mathrm{FEV}_{6}$, initial oxygen saturation (pre-1SWT SpO ${ }_{2}$ ), ISWD, pre-ISWT HR, post-ISWT HR, or percentage of maximal HR (Table 1). The BMl was significantly higher in those who developed oxygen desaturation $(p=0.01)$, and post-ISWT $\mathrm{SpO}_{2}$ was significantly different between the two groups $(p<0.0001)$.

\section{Discussion}

In 66 subjects, post-1SWT oxygen saturation values were quite similar to pre-1SWT oxygen saturation values, a finding that was expected because of the intensity of the exercise performed. In 11 subjects, post-ISWT SpO $\mathrm{S}_{2}$ values were higher than pre-1SWT $\mathrm{SpO}_{2}$ values. This finding is not unusual, given that physical activity improves ventilation and alveolar recruitment. However, $17(20.7 \%)$ of the 83 individuals in the study sample showed a significant drop in oxygen saturation during the 1SWT ( $\Delta$ sat $\geq 4 \%$ ). This was an unexpected finding, and there is little information in the literature regarding what happens with oxygen saturation after the ISWT in healthy subjects.

Exercise-induced hypoxemia in athletes is arbitrarily defined as a decrease in $\mathrm{PaO}_{2}$ of approximately $7.5 \mathrm{mmHg},{ }^{(7)}$ an $\mathrm{SaO}_{2}$ below $95 \%$, or both; extreme cases will show an $\mathrm{SaO}_{2}$ of less than $88 \% .{ }^{(9)}$ Oxygen uptake increases during exercise in order to meet the needs imposed by an increased metabolic rate and correlate with work intensity until all subjects achieve maximal oxygen uptake. ${ }^{(10)}$ Each step of oxygen transport from ambient air to the cells can limit whole-body oxygen uptake, and circulation has been considered the most important factor limiting maximal oxygen uptake during large muscle mass exercise.

A decrease in $\mathrm{PaO}_{2}$ and $\mathrm{SaO}_{2}$ is quite common during maximal ergometer rowing. ${ }^{(11)}$ In such subjects, cardiac output can exceed $30 \mathrm{~L} / \mathrm{min}$; under such circumstances, the ability to renew alveolar air and maintain high oxygen partial pressures, the diffusion resistance to oxygen at the alveolar-capillary membrane, the reduction in red blood cell transit time in the pulmonary capillary, 
and the increased probability of ventilation/ perfusion mismatch are critically important to oxygen uptake. ${ }^{(12)}$

The prevalence of exercise-induced hypoxemia seems to be as high as 50\%. ${ }^{(13)}$ Exercise intensity determines the degree of hypoxemia. ${ }^{(14)}$ Oxygen desaturation is also more pronounced during whole-body exercise, such as rowing or running, than during leg exercise, and leg exercise is more capable of inducing hypoxemia than is arm exercise. (14) This suggests that the amount of muscle mass involved in the exercise influences the development of oxygen desaturation.

In 1984, Dempsey et al. ${ }^{(15)}$ studied the incidence of exercise-induced arterial hypoxemia in 16 highly trained healthy runners who were capable of achieving and sustaining very high metabolic rates, including a maximal oxygen uptake of $72 \pm$ $2 \mathrm{~mL} / \mathrm{kg}$. Arterial blood gases and acid-base status were determined at each load of a progressive short-term exercise test and repeatedly determined during constant-load treadmill running. Three types of response were encountered and were quite reproducible within subjects: four runners maintained $\mathrm{PaO}_{2}$ within $10 \mathrm{mmHg}$ of resting values; another four showed a decrease of 10-15 $\mathrm{mmHg}$ in $\mathrm{PaO}_{2}$; and the remaining eight runners showed remarkably decreased $\mathrm{PaO}_{2}$. The decrease in $\mathrm{PaO}_{2}$ ranged from $21 \mathrm{mmHg}$ to $35 \mathrm{mmHg}$, $\mathrm{PaO}_{2}$ having decreased to less than $75 \mathrm{mmHg}$ in all cases and to less than $60 \mathrm{mmHg}$ in two cases. During constant-load exercise, $\mathrm{PaO}_{2}$ was often maintained during the initial $30 \mathrm{~s}$, when hyperventilation was greatest; subsequently, hypoxemia occurred, the severity of hypoxemia having either remained the same or worsened over the ensuing 3-4 $\mathrm{min}$ in most of the cases. The most severe hypoxemia during heavy exercise was associated with an (estimated) alveolar oxygen tension to a (measured) $\mathrm{PaO}_{2}$ difference in excess of $40 \mathrm{mmHg}$. The analysis of all of the variables measured during the investigation led the authors to hypothesize that the observed hypoxemia was attributable to a diffusion limitation secondary to very short red cell transit times in at least a portion of the pulmonary circulation; such short transit times can occur at high metabolic rates. Tidal breathing during heavy exercise can frequently exceed the maximal flow-volume curve, and hyperventilation can be limited by the mechanical load on the chest wall secondary to increased pulmonary impedance, a situation that can also impair the renewal of alveolar air.

Although it has been described as an incremental field walking test that produces a symptomlimited maximal performance, the ISWT cannot be compared with the maximal exercise tests cited above. Nevertheless, 17 healthy subjects showed oxygen desaturation after the ISWT in the present study. The only significant difference between the individuals who developed oxygen desaturation and those who did not was that the BMl was higher in the former. This finding is consistent with the hypothesis that the lungs, during physical activities that cause the HR to get closest to the maximal HR expected for a given subject, are unable to arterialize the fast flowing blood, especially in those subjects whose needs are amplified because of a higher body mass. Although Durand et al. ${ }^{(16)}$ found no differences in height, weight, or lung volume between athletes who developed oxygen desaturation and those who did not, it can be argued that the proportions of those variables are more important than their absolute values.

Our findings and the data from the literature lead to a worrisome possibility: oxygen desaturation during aerobic activity is probably more common than previously thought and can pose a threat to high-performance athletes that has been systematically overlooked. Although the occurrence of oxygen desaturation is acknowledged in studies that date back to the second half of the last century, none of those studies elaborated on the potential harmful effects of such periods of intermittent hypoxemia.

We are unaware of any evaluation protocol for high-performance aerobic training that includes the determination of exercise-induced oxygen desaturation. Given that sudden death is relatively common in athletes, screening for oxygen desaturation seems justified.

Sudden cardiac death (SCD) is considered the leading cause of death in young athletes. The true incidence of SCD is unknown and highly underestimated. The studies reporting the highest incidence estimated that up to 110 deaths occur each year in young athletes, which is equivalent to 1 death every 3 days in the United States. (17) The available evidence points to a structural cardiac abnormality as the underlying cause of SCD. Hypertrophic cardiomyopathy and coronary artery anomalies account for approximately $25 \%$ and $14 \%$, respectively, of all SCDs in the 
United States. ${ }^{(18)}$ Arrhythmogenic right ventricular cardiomyopathy/dysplasia is a cardiac disease characterized by myocardial necrosis followed by fibrofatty replacement. These altered myocardial areas constitute the anatomical substrate for reentry circuits that propitiate the onset of ventricular arrhythmias. ${ }^{(19)}$ This last condition can be particularly significant in the context of the present study. Oxygen desaturation during intense physical activity can cause repeated episodes of hypoxic pulmonary vascular constriction and pulmonary hypertension. The walls of the right ventricle can suffer during these episodes, to the point of myocardial necrosis, fibrofatty replacement being the expected consequence of this kind of stress.

Another common cause of SCD is Brugada syndrome, ${ }^{(20)}$ which is characterized by an ST-segment elevation in the right precordial electrocardiogram leads followed by a negative T wave. The worldwide prevalence of Brugada syndrome is estimated at 1-5 per 10,000 population, although it is higher in Southeast Asia. ${ }^{(21)}$ Brugada syndrome is traditionally thought of as a primary electrical cardiac disease arising in myocardium that is otherwise structurally normal. However, magnetic resonance imaging, positron emission tomography, and pathological evaluation of biopsy specimens have identified structural abnormalities in many patients with a diagnosis of Brugada syndrome, including fibrofatty replacement of the right ventricular free wall and fibrotic disruption of the right bundle branch.

It is established in the literature that Brugada syndrome is the result of an autosomal dominant mutation in the SCN5A gene on chromosome 3, resulting in a loss of function sodium channel abnormality. ${ }^{(22)}$ It has become increasingly clear that ion channel gene expression is highly dynamic and can respond to many environmental stimuli. (23) Hypoxemia is possibly one of these stimuli. Therefore, a genetic predisposition to cardiac arrhythmia does not preclude the superimposition of hypoxemia causing the sudden deaths of young people or athletes.

The data in the present study and the accumulated knowledge regarding oxygen desaturation during physical activity raise the hypothesis that hypoxemia during exercise can be dangerous and suggest that it is advisable to include a screening test for oxygen desaturation in the evaluation protocols for endurance athletes. Further studies are needed in order to explore this hypothesis.
In conclusion, because of the possibility of oxygen desaturation in healthy individuals undergoing the ISWT, the use of the ISWT to predict the presence of subtle respiratory abnormalities undetected by submaximal tests such as the 6MWT can be misleading. The finding that oxygen desaturation is common in healthy subjects undergoing the ISWT adds to the knowledge that oxygen desaturation during intense physical activity is quite common and can have deleterious effects.

\section{References}

1. Hallstrand TS, Boitano LJ, Johnson WC, Spada CA, Hayes JG, Raghu G. The timed walk test as a measure of severity and survival in idiopathic pulmonary fibrosis. Eur Respir J. 2005;25(1):96-103. http://dx.doi.org/10.1183/09031 936.04.00137203 PMid:15640329

2. Morales-Blanhir JE, Palafox Vidal CD, Rosas Romero Mde J, García Castro MM, Londo-o Villegas A, Zamboni M. Six-minute walk test: a valuable tool for assessing pulmonary impairment. J Bras Pneumol. 2011;37(1):110-7. http://dx.doi.org/10.1590/S1806-37132011000100016 PMid:21390439

3. King TE Jr, Tooze JA, Schwarz Ml, Brown KR, Cherniack RM. Predicting survival in idiopathic pulmonary fibrosis: scoring system and survival model. Am J Respir Crit Care Med. 2001;164(7):1171-81. http://dx.doi.org/10.1164/ ajrccm.164.7.2003140 PMid:11673205

4. King TE Jr, Schwarz Ml, Brown K, Tooze JA, Colby TV, Waldron JA Jr, et al. Idiopathic pulmonary fibrosis: relationship between histopathologic features and mortality. Am J Respir Crit Care Med. 2001;164(6):1025-32. http:// dx.doi.org/10.1164/ajrccm.164.6.2001056 PMid:11587991

5. Lama VN, Flaherty KR, Toews GB, Colby TV, Travis WD, Long Q, et al. Prognostic value of desaturation during a 6-minute walk test in idiopathic interstitial pneumonia. Am J Respir Crit Care Med. 2003;168(9):1084-90. http:// dx.doi.org/10.1164/rccm.200302-2190C PMid:12917227

6. Villalba WO, Sampaio-Barros PD, Pereira MC, Cerqueira EM, Leme CA Jr, Marques-Neto JF, et al. Six-minute walk test for the evaluation of pulmonary disease severity in scleroderma patients. Chest. 2007;131(1):217-22. http:// dx.doi.org/10.1378/chest.06-0630 PMid:17218579

7. Singh SJ, Morgan MD, Scott S, Walters D, Hardman AE. Development of a shuttle walking test of disability in patients with chronic airways obstruction. Thorax. 1992;47(12):1019-24. http://dx.doi.org/10.1136/ thx.47.12.1019 PMid:1494764 PMCid:PMC1021093

8. Prefaut C, Durand F, Mucci P, Caillaud C. Exercise-induced arterial hypoxaemia in athletes: a review. Sports Med. 2000;30(1):47-61. http://dx.doi.org/10.2165/00007256200030010-00005 PMid:10907757

9. Dempsey JA, Wagner PD. Exercise-induced arterial hypoxemia. J Appl Physiol. 1999;87(6):1997-2006. PMid:10601141

10.Dourado VZ, Guerra RL, Tanni SE, Antunes LC, Godoy 1. Reference values for the incremental shuttle walk test in healthy subjects: from the walk distance to physiological responses. J. Bras. Pneumol. 2013;39(2):190-7. http://dx.doi. org/10.1590/S1806-37132013000200010 PMid:23670504 
11. Nielsen HB, Madsen P, Svendsen LB, Roach RC, Secher NH. The influence of $\mathrm{PaO} 2, \mathrm{pH}$ and $\mathrm{SaO} 2$ on maximal oxygen uptake. Acta Physiol Scand. 1998;164(1):89-7. http://dx.doi. org/10.1046/j.1365-201X.1998.00405.x PMid:9777029

12.Nielsen HB. pH after competitive rowing: the lower physiological range? Acta Physiol Scand. 1999.;165(1):113-4. http://dx.doi.org/10.1046/j.1365-201x.1999.00485.x PMid:10072104

13.Powers SK, Dodd S, Lawler J, Landry G, Kirtley M, McKnight $\mathrm{T}$, et al. Incidence of exercise induced hypoxemia in elite endurance athletes at sea level. Eur J Appl Physiol Occup Physiol. 1988;58(3):298-302. http://dx.doi.org/10.1007/ BF00417266 PMid:3220070

14. Nielsen HB. Arterial desaturation during exercise in man: implication for $\mathrm{O} 2$ uptake and work capacity. Scand J Med Sci Sports. 2003;13(6):339-58. http://dx.doi.org/10.1046/ j.1600-0838.2003.00325.x PMid:14617055

15.Dempsey JA, Hanson PG, Henderson KS. Exerciseinduced arterial hypoxaemia in healthy human subjects at sea level. J Physiol. 1984;355:161-75. PMid:6436475 PMCid:PMC1193484

16.Durand F, Mucci P, Préfaut C. Evidence for an inadequate hyperventilation inducing arterial hypoxemia at submaximal exercise in all highly trained endurance athletes. Med Sci Sports Exerc. 2000;32(5):926-32. http://dx.doi. org/10.1097/00005768-200005000-00008 PMid:10795782

17.Casa DJ, Guskiewicz KM, Anderson SA, Courson RW, Heck JF, Jimenez CC, et al. National athletic trainers' association position statement: preventing sudden death in sports. J Athl Train. 2012;47(1):96-118. PMid:22488236 PMCid:PMC3418121

18.Maron BJ. Sudden death in young athletes. N Engl J Med. 2003;349(11):1064-75. http://dx.doi.org/10.1056/ NEJMra022783 PMid:12968091

19.Bauce B, Daliento L, Frigo G, Russo G, Nava A. Pregnancy in women with arrhythmogenic right ventricular cardiomyopathy/dysplasia. Eur J Obstet Gynecol Reprod Biol. 2006;127(2):186-9 http://dx.doi.org/10.1016/j. ejogrb.2005.10.011 PMid:16337730

20.Brugada P, Brugada J. Right bundle branch block, persistent ST segment elevation and sudden cardiac death: a distinct clinical and electrocardiographic syndrome. A multicenter report. J Am Coll Cardiol. 1992;20(6):1391-6. http://dx.doi. org/10.1016/0735-1097(92)90253-J

21.Antzelevitch C. Brugada syndrome. Pacing Clin Electrophysiol. 2006;29(10):1130-59. http://dx.doi.org/10.1111/j.15408159.2006.00507.x PMid:17038146 PMCid:PMC1978482

22.Walker J, Calkins H, Nazarian S. Evaluation of cardiac arrhythmia among athletes. Am J Med. 2010;123(12):107581. http://dx.doi.org/10.1016/j.amjmed.2010.05.008 PMid:20870195 PMCid:PMC3010317

23. Hilber K. Skeletal myocyte plasticity: basis for improved therapeutic potential? Curr Opin Pharmacol. 2008;8(3):32732. http://dx.doi.org/10.1016/j.coph.2008.01.007 PMid:18329336 PMCid:PMC2957812

\section{About the authors}

\section{Daniel Machado Seixas}

Professor of Physical Education. State University at Campinas, Campinas, Brazil.

\section{Daniela Miti Tsukumo Seixas}

Physician. State University at Campinas, Campinas, Brazil.

\section{Monica Corso Pereira}

Physician. State University at Campinas, Campinas, Brazil.

\section{Marcos Mello Moreira}

Respiratory Diseases Service. State University at Campinas, Campinas, Brazil.

\section{Ilma Aparecida Paschoal}

Associate Professor. State University at Campinas, Campinas, Brazil. 